\title{
Study of Adenosine Deaminase Levels Along With Alanine and Aspartate Aminotransferase, Total Proteins and A/G Ratio in Cirrhosis
}

\author{
N. N. Sreedevi ${ }^{1}$, A. Chakrapani ${ }^{2}$ \\ ${ }^{I}$ Assistant professor, Dept. of Biochemistry, Bhaskara Medical College, Hyderabad, A.P, NTRUHS, India \\ ${ }^{2}$ Associate professor, Dept. of surgery, Govt. Medical college Nizamabad, Hyderabad, A.P, NTRUHS, India
}

\begin{abstract}
Liver is the most bio-chemically complex organ. It plays a vital role in the metabolism and in the detoxification and elimination of toxic substances. Alcohol is the most common cause of hepatic injury terminating in cirrhosis. Acetaldehyde metabolite formed during the metabolism of ethanol is very reactive compound and is the mediator of tissue and organ damage. Many individuals with liver disease maintain normal function despite extensive liver damage. In such cases measurement of liver enzymes which are released into circulation as a result of liver cell injury, through non-specific may be helpful to assess the severity of liver damage. Main aim of the study is to evaluate the serum adenosine deaminase activity (ADA) along with other known markers of liver function such as alanine aminotransferase (ALT), aspartate aminotransferase (AST),, Total proteins and $A / G$ ratio in patients with alcoholic cirrhosis, infective hepatitis and to assess the utility of these parameters as diagnostic and prognostic indicators of liver function. This study was done at Gandhi Hospital secunderabad; The patients included in the study were selected from out-patient and wards of Gastroenterology department of Gandhi hospital. Oral informed consent was taken from the persons who were included in the study. 12 individuals aged between 25-60 yrs were taken as controls. Most of them were males. 12 patients clinically diagnosed as alcoholic cirrhosis, confirmed by history, abdominal ultrasound scan and altered liver functions and 11 patients with viral hepatitis(serologically positive for HbsAg) were selected for study. In our study raised serum ADA levels are seen in cirrhosis patients when compared to normal individuals. Serum transaminases showed moderate raise when compared to normal individuals. Serum AST levels were greater than ALT. The serum AST: ALT ratio is >1. The total serum proteins showed marked reduction when compared to normal individuals. Serum albumin is reduced to greater extent. Serum globulins were increased when compared to normal individuals, resulting in reversal of normal A/G ratio. The reverse of $A / G$ ratio indicates the severity of disease.
\end{abstract}

Keywords: Cirrhosis, Adenosine deaminase, Alanine, Aspartate aminotransferase, Total proteins and A/G ratio

\section{Introduction}

Chronic consumption of alcohol often leads to three distinctive, overlapping, forms of liver diseases. Hepatic steatosis, Alcoholic hepatitis, and Cirrhosis, collectively referred to as alcoholic liver desease (ALD). Alcohol is the most common cause of liver disease although it is entirely preventable. It is the $4^{\text {th }}$ commonest cause of death in males and $5^{\text {th }}$ in women in U.S.A. The causal connection between excess alcohol and cirrhosis was noted by Baillie in 1793 only 10-30\% of heavy persistent alcoholic drinkers develop cirrhosis, although well over $50 \%$ may have fatty liver. Susceptibility of individuals to develop cirrhosis depends upon amount and duration of alcohol consumption, genetic factors and also depends upon many other factors.

\section{Risk Factors:}

Quantity:It mean $40-80 \mathrm{~g} / \mathrm{d}$ of ethanol produces fatty liver, $160 \mathrm{~g} / \mathrm{d}$ for $10-20$ yrs causes hepatitis or cirrhosis, and only $15 \%$ of alcoholics develop alcoholic liver disease.

Gender:Women with reduced activities of alcohol dehydrogenase are more susceptible to alcoholic liver disease at quantities $>20 \mathrm{~g} / \mathrm{d}$.

Hepatitis C: HCV antibodies are isolated from chronic alcoholics so alcoholics with concurrent HCV infection are associated with severe liver damage.

Nutrition: The contribution of nutrition to the development of ALD remains controversial but it seems possible that under nutrition and direct alcohol toxicity synergistically increase the likelihood of liver disease.

Genetic factors: Individual susceptibility to both alcoholism and alcoholic liver damage has important components.

Several possible biological markers of alcoholism have been described. These include (i) The A1 allele of the D2 dopamine receptor in the brain, present in significantly more alcoholics than controls.(ii)MONO 
AMINEOXIDSASE B activity in platelets, this enzyme, which catalyses the oxidation of mono-amine neurotransmitter is present in two iso-forms one of these, the B-form is present in platelets and its activity is decreased in alcoholics.(iii) P-300 - Event related potentials. These potentials measure brain-wave response to external sensory stimuli by computer averaging. One part of event related potential is a positive wave occurring about 300ms (the P-300) after a sensory stimulus. Several studies have found reduced P-300 in alcoholics, former alcoholics, and in young sons of alcoholics. The P-300 measures the sensory, perceptual and cognitive responses of an individual.

Variations in the genes encoding the two principal alcohol metabolizing enzymes-alcohol and aldehyde dehydrogenase (ADH and ALDH) have been observed. The ADH iso-enzyme sub-units are encoded by at least seven different loci and polymorphism have been identified in two, ADH2 and ADAH3. The isoenzymes arising from these subunits oxidize alcohol to acetaldehyde at widely differing rates. The most important iso-enzyme for acetaldehyde metabolism is encoded by ALDH2 locus; about 50\% of oriental possess a dominant null allele that encodes an inactive form of the enzyme. Individuals with the more active forms of $\mathrm{ADH}$, and hence more rapid product ion of acetaldehyde, or the inactive form of ALDH2 and slower metabolism of acetaldehyde, are less likely to be alcoholic, due to the aversive effects of acetaldehyde in the circulation - the alcohol flush. Metabolic analysis of two recent European studies suggests that possession of the active form of $\mathrm{ADH} 3$, and hence more rapid production of acetaldehyde, may carry an increased risk of the development of cirrhosis.

ETHNNOL METABOLISM: First pass metabolism of ethanol occurs in the stomach mediated by gastric $\mathrm{ADH}$, thus delivering less ethanol load to the liver. Liver is the major organ involved in the metabolic disposal of the ethanol. Ethanol is metabolized oxidative and non-oxidatively. Ethanol metabolism are extra mitochondrial, there are intimately linked with mitochondrial energy metabolism.Oxidative pathway; ethanol is oxidized through one major and two accessory pathways. Ethanol oxidation in the liver is catalyzed predominantly by ADH in the cytosol.The cytochrome p-450 pathway: This utilizes NADPH \& molecular oxygen and is located in ER, which is referred to as Microsomal Ethanol oxidizing system. This pathway operates in chronic alcoholics due to selective induction by ethanol of a specific high $\mathrm{km}$ cytochrome $\mathrm{p}-450$ isoform called p-450 2El which uses ethanol as substrate.Ethanol oxidation also occurs in peroxisomes mediated by catalaseAll oxidative routes for ethanol metabolism result in the formation acetaldehyde. This metabolite is further metabolized to acetate; primarily by low $\mathrm{km}$ aldehyde dehydrogenase localized in mitochondria. This enzyme is found in many tissues, where the rate of acetaldehyde formation is highest. The acetate formed is further metabolized by the Krebs cycle

Non-oxidative pathways of ethanol oxidation include the formation of ethyl esters of long - chain fatty acids, mediated by isoenzymes of flutathione s-transferase and by a cholesterol esterase these compounds have been reported to affect mitochondrial function acting as uncouplers, with a decreased state 3 respirations and increased state 4 respirations these fatty acid ethyl esters are detected in alcoholic patients in several tissues affected by long-term alcohol abuse. Thus, both the oxidative and non-oxidative metabolism of alcohol generate the intermediates that initiate a cascade of events critical for the development of the illness including the targeting of mitochondria and subsequent dysfunction

\section{Materials \& Method}

This study was done at Gandhi Hospital secunderabad; The patients included in the study were selected from out-patient and wards of Gastroenterology department of Gandhi hospital. Oral informed consent was taken from the persons who were included in the study. 12 individuals aged between 25-60 yrs were taken as controls. Most of them were males. 12 patients clinically diagnosed as alcoholic cirrhosis, confirmed by history, abdominal ultrasound scan and altered liver functions and 11 patients with viral hepatitis(serologically positive for $\mathrm{HbsAg}$ ) were selected for study.

EXCLUSION CRITERIA:Patients with other diseases such as diabetes mellitus, cardiovascular diseases, hypertension, kidney disease were excluded from the study.

SAMPLE COLLECTION:Venous samples were collected in plain tubes under aseptic precautions. The blood was allowed to stand for 30- 40 min's at room temperature for clot formation and separation of serum. Precautions were taken to prevent haemolysis. Then it was centrifuged and serum was collected, which was then immediately analyzed for serum enzymes AST, ALT, ADA, Total proteins and A/G ratio.

DETERMINATION OF ADENOSINE DEAMINASE ACTIVITY IN SERUM :Serum ADA levels were estimated by the kit method provided by Tulip diagnostics Ltd. ${ }^{39}{ }^{40}$.PRINCIPLE:Adenosine deaminase hydrolysis adenosine to ammonia and inosine. The ammonia formed further reacts with a phenol and hypochlorite in an alkaline medium to form a blue indophenol complex with sodium nitroprusside acting as a catalyst. Intensity of the blue coloured indophenol complex formed is directly proportional to the amount of ADA present in the sample 
Estimation of SGPT(ALT)IFCC Method, KineticThis reagent kit is intended for in vitro quantitative determination of ALT activity in serum or plasma. ${ }^{41}$ principle. There is a decrease in absorption at $340 \mathrm{~nm}$ as NADH is converted to NAD. The rate of decrease in absorbance is measure and is proportional to SGPT activity in the sample. It is recommended that each laboratory establish its own reference values. The following value may be used as a guideline. SGPT(ALT)Serum/Plasma: Up to $49 \mathrm{U} / \mathrm{L}\left(37^{0} \mathrm{C}\right)$

ESTIMATION OF SGOT(AST)IFCC METHOD, KINETIC.This reagent kit is intended for in vitro quantitative determination of AST activity in serum or plasma. ${ }^{42}$ principle:There is a decrease in absorption at $340 \mathrm{~nm}$ as NADH is converted to NAD. The rate of decrease in absorbance is measured and is proportional to AST activity in the sample. It is recommended that each laboratory establish its own reference values. The following value may be used as a guideline,SGOT(AST)Serum/Plasma : Up to $46 \mathrm{U} / \mathrm{L}\left(37^{0} \mathrm{C}\right)$

ESTIMATION OF SERUM PROTIENS is by(BIURET METHOD).PRINCIPLE:In an alkaline medium, total protein reacts with the copper of biuret reagent causing an increase in absorbance. The increase in absorbance, at $546 \mathrm{~nm}(530-570 \mathrm{~nm})$ or with green filter) is due to formation of the violet colored complex and it is directly proportional to the concentration of protein present in the sample. ${ }^{43,44 .}$
ESTIMATION
OF SERUM
ALBUMINBROMOCRESOL
GREEN
DYEBINDING METHOD.PRINCIPLE:

Determination of Albumin in serum or plasma is based on the binding behavior of albumin with dye $33^{\prime} 55^{\prime}$ tetrabromo $\mathrm{M}$ cresol sulfonpthalien (BCG) in acidic medium at $\mathrm{pH}$ 4.2. The blue green colored complex is formed, the Conc. Of which is proportional to the albumin present in the sample and it is measured at $600 \mathrm{~nm}$. (600-650nm or with red filter). ${ }^{45}$

\section{Results}

The present study consist of 35 subjects which were studied under three groups.

\begin{tabular}{|l|l|l|}
\hline Group I & Controls & 12 \\
\hline Group II & Cirrhosis & 12 \\
\hline Group III & Viral Hepatitis & 11 \\
\hline \multicolumn{3}{|c}{ Table 1 }
\end{tabular}

For the collected data serum enzymes and serum proteins statistical analysis was done by applying analysis of variance (ANOVA) or ' $\mathrm{F}$ ' test. ALT and AST are non-parametric so they were subjected to mannwhitney test. Post -Hoc multiple comparison test was used to compare pairs of groups which were significant from each other. Difference between various groups were considered significant at $\mathrm{P}<0.001$.

STUDY OF CONTROL GROUP-I:_In the control group the mean values of ALT, AST, ADA, Total Proteins, $\mathrm{A} / \mathrm{G}$ ratio were within the established normal limits ( Refer Table 2). In the control groups the mean, Standard Deviation (SD), Standard Error of Mean (SEM) of ADA was 20.08, $\pm 6.7, \pm 2.0$ COMPARISION OF GROUP I AND GROUP II: The mean, SD and SEM of ALT, AST, and ADA are 50.92 \pm 7.14, 57.25 \pm 8.58 . $(64.08 \pm 5.90)$ respectively they showed statistically increased values when compare to control group. The total proteins decrease to $5.62 \pm 0.44$. serum albumin was decreased to $2.09, \pm 0.202$, while serum globulins were increased to 3.52 0.322.;COMPARISION OF GROUP I \& GROUP III :- The mean, SD, SEM of ALT and AST have increased $183.45, \pm 66.478 ; 93, \pm 34.765$ respectively, when compared to group I AST,ALT values have increased significantly. While the mean value of ADA showed an elevation of $40.73, \pm 5.274$ when compared to normal. Total proteins showed no significant variation.COMPARISION OF GROUP II \& GROUP III: The mean, SD and SEM of ALT and AST of group III are 183.45 $\pm 66.47,93.00 \pm 34.765$ showed significant raise when compared to group II $50.92 \pm 7.14,57.25 \pm 8.58$. The serum ADA levels are moderately increased in group III $(40.73 \pm 5.27)$ when compared to group II $(64.08 \pm 5.90)$. The serum proteins were normal in group III (6.636 \pm 0.366$)$. But group II showed marked reduction in total proteins ( $5.617 \pm 0.446)$. The serum albumin $(2.09 \pm 0.202)$ and globulins $(3.525 \pm 0.322)$ were reduced than group III $(3.72 \pm 0.342)(2.827 \pm 0.475)$ which were normal.

Table 1:Mean and Standard Deviations in Three Groups

\begin{tabular}{|l|l|l|l|}
\hline & Group I & Group II & Group III \\
\hline ALT U/L & Control & Cirrhosis & Viral Hepatitis \\
\hline AST U/L & $13.92 \pm 4.48$ & $50.92 \pm 7.14$ & $183.45 \pm 66.47$ \\
\hline ADA U/L & $11.25 \pm 2.26$ & $57.25 \pm 8.58$ & $93 \pm 34.76$ \\
\hline Total proteins g/dl & $20.08 \pm 6.97$ & $64.08 \pm 5.90$ & $40.73 \pm 5.27$ \\
\hline Albumin g/dl & $4.12 \pm 0.382$ & $5.617 \pm 0.44$ & $6.6 \pm 0.366$ \\
\hline Globulin g/dl & $2.442 \pm 0.23$ & $2.09 \pm 0.202$ & $3.72 \pm 0.343$ \\
\hline \multicolumn{4}{|c|}{} \\
\hline
\end{tabular}

Table 2

Alanine Aminotransferase (ALT) levels were statistically significant in Cirrhosis $(\mathrm{p}<0.001)$ and Viral Hepatitis $(\mathrm{P}<0.001)$ as compared to normal control group. The ALT values were significantly raised in Viral Hepatitis when compared to Cirrhosis.Aspartate Aminotransferase (AST) levels were significantly raised in 
Study of Adenosine Delaminate Levels Along With Almandine and Aspartame Aminotransferase,

Cirrhosis and Viral Hepatitis $(\mathrm{P}<0.01)$ as compared to normal. Adenosine Deaminase (ADA) levels are significantly raised in Cirrhosis $(\mathrm{P}<0.001)$. The ADA activities in the Viral Hepatitis are higher than the control group $(\mathrm{P}<0.01)$. Total Proteins were reduced in Cirrhosis and is extremely statistically significant and were normal in Viral Hepatitis.Albumin levels were decreased in Cirrhosis, in Viral Hepatitis were not significantly changed as compared to normal.Globulins were significantly raised in Cirrhosis as compared to normal. In Viral Hepatitis levels been normal.A/G ratio is altered in cirrhosis which is statistically significant when compared to control group. Viral hepatitis group showed no variation when compared to control group.

\begin{tabular}{|c|c|c|c|c|c|c|c|c|c|c|c|c|c|}
\hline & \multicolumn{6}{|c|}{ Group I -- control } & & \multicolumn{6}{|c|}{ Group II - Crishosis } \\
\hline $\begin{array}{l}\text { SN } \\
\mathbf{O}\end{array}$ & $\begin{array}{l}\mathbf{A L} \\
\mathbf{T}\end{array}$ & AST & ADA & $\begin{array}{l}\text { T } \\
\text { Proteins }\end{array}$ & ALB & $\begin{array}{l}\text { Glob } \\
\text { ulins }\end{array}$ & SNO & ALT & AST & $\begin{array}{l}\text { AD } \\
\text { A }\end{array}$ & $\begin{array}{l}\text { T } \\
\text { Protein } \\
\text { S }\end{array}$ & $\begin{array}{l}\text { Albumi } \\
\text { n }\end{array}$ & $\begin{array}{l}\text { Globulin } \\
\text { s }\end{array}$ \\
\hline 1 & 12 & 9 & 15 & 6.5 & 4 & 2.5 & 1 & 54 & 56 & 58 & 5.5 & 2 & 3.5 \\
\hline 2 & 12 & 14 & 18 & 6.9 & 4.1 & 2.8 & 2 & 54 & 52 & 60 & 5.8 & 2.2 & 3.6 \\
\hline 3 & 8 & 10 & 19 & 7 & 4.5 & 2.5 & 3 & 52 & 70 & 62 & 6 & 2 & 4 \\
\hline 4 & 20 & 10 & 14 & 6.8 & 4 & 2.8 & 4 & 42 & 46 & 63 & 6.2 & 2.2 & 4 \\
\hline 5 & 11 & 16 & 17 & 6 & 3.9 & 2.1 & 5 & 60 & 68 & 75 & 5.6 & 2.2 & 3.4 \\
\hline 6 & 24 & 13 & 25 & 6.4 & 4 & 2.4 & 6 & 52 & 54 & 64 & 5.2 & 1.8 & 3.4 \\
\hline 7 & 13 & 11 & 15 & 7.2 & 4.8 & 2.4 & 7 & 45 & 66 & 70 & 5.2 & 1.8 & 3.4 \\
\hline 8 & 9 & 8 & 20 & 6.2 & 3.8 & 2.4 & 8 & 62 & 52 & 65 & 5 & 2 & 3 \\
\hline 9 & 13 & 10 & 15 & 6.6 & 4.5 & 2.1 & 9 & 53 & 64 & 72 & 5.4 & 2 & 3.4 \\
\hline 10 & 15 & 12 & 32 & 6 & 3.5 & 2.5 & 10 & 42 & 48 & 66 & 5.3 & 2.1 & 3.2 \\
\hline 11 & 14 & 10 & 35 & 6.4 & 3.8 & 2.6 & 11 & 55 & 60 & 56 & 5.7 & 2.3 & 3.4 \\
\hline 12 & 16 & 12 & 16 & 6.7 & 4.5 & 2.2 & 12 & 40 & 45 & 58 & 6.5 & 2.5 & 4 \\
\hline $\begin{array}{l}\mathrm{Me} \\
\text { an }\end{array}$ & $\begin{array}{l}13.9 \\
2 \\
\end{array}$ & 11.25 & 20.08 & 6.56 & 4.12 & 2.44 & $\begin{array}{l}\text { Mea } \\
\mathrm{n}\end{array}$ & $\begin{array}{l}50.9 \\
2\end{array}$ & $\begin{array}{l}57.2 \\
5 \\
\end{array}$ & $\begin{array}{l}64.0 \\
8 \\
\end{array}$ & 5.62 & 2.09 & 3.53 \\
\hline SD & 4.29 & 2.26 & 6.97 & 0.38 & 0.38 & 0.23 & \multirow[t]{2}{*}{ SD } & \multirow[t]{2}{*}{7.14} & & \multirow[t]{2}{*}{5.90} & \multirow[t]{2}{*}{0.45} & \multirow[t]{2}{*}{0.20} & \multirow[t]{2}{*}{0.32} \\
\hline SE & 1.33 & 0.65 & 2.01 & 0.11 & 0.11 & 0.07 & & & 8.58 & & & & \\
\hline M & & & & & & & SEM & 2.06 & 2.48 & 1.70 & 0.13 & 0.06 & 0.09 \\
\hline
\end{tabular}
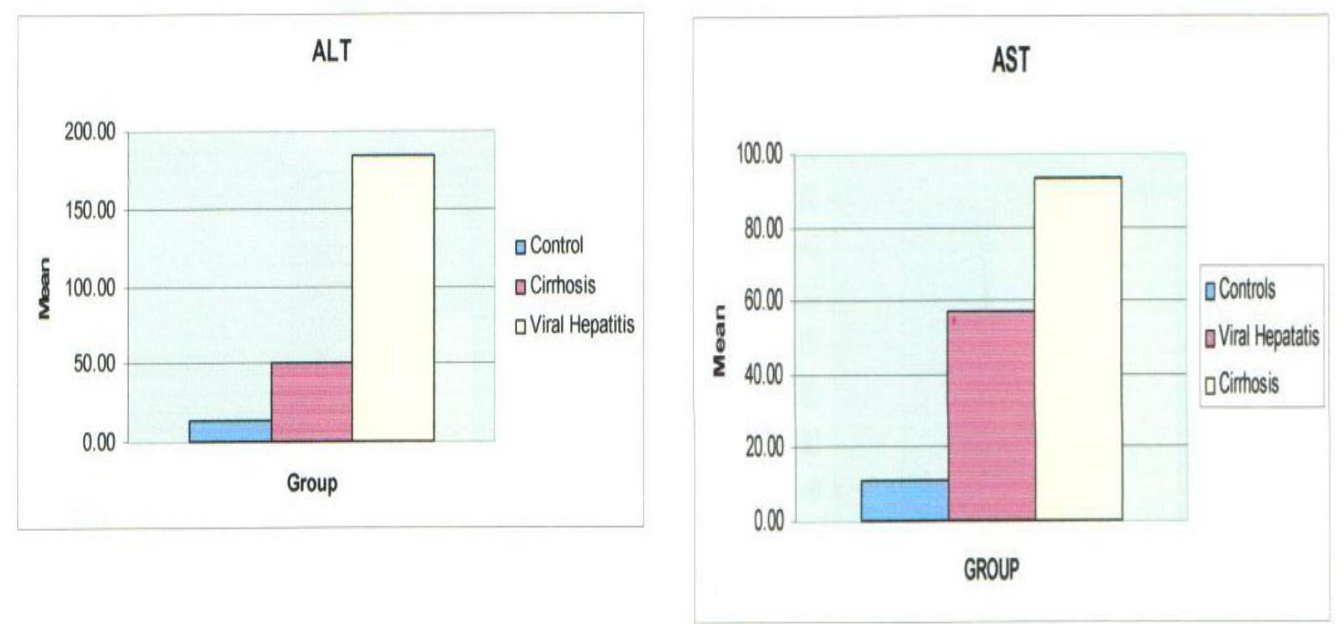

\begin{tabular}{|l|l|l|l|l|l|l|}
\hline \multicolumn{7}{|l|}{ Group III - Viral Hepatitis } \\
\hline SNO & ALT & AST & ADA & T Proteins & Albumin & Globulins \\
\hline 1 & 140 & 80 & 46 & 6.5 & 4 & 2.5 \\
\hline 2 & 198 & 71 & 38 & 7.3 & 4.2 & 3.1 \\
\hline 3 & 220 & 160 & 40 & 6.7 & 3.9 & 2.8 \\
\hline 4 & 200 & 90 & 42 & 6.4 & 4.2 & 2.2 \\
\hline 5 & 250 & 61 & 53 & 6.2 & 3.4 & 2.8 \\
\hline 6 & 120 & 84 & 39 & 7 & 4.2 & 2.8 \\
\hline 7 & 240 & 121 & 44 & 6.1 & 3.5 & 2.6 \\
\hline 8 & 90 & 71 & 36 & 7 & 4 & 3 \\
\hline 9 & 300 & 150 & 37 & 6.8 & 3.9 & 2.9 \\
\hline 10 & 150 & 65 & 38 & 6.4 & 3.7 & 2.7 \\
\hline 11 & 110 & 70 & 35 & 6.5 & 3.9 & 2.6 \\
\hline Mean & 183.45 & 93.00 & 40.73 & 6.63 & 3.90 & 2.73 \\
\hline SD & 66.48 & 34.76 & 5.27 & 0.37 & 0.27 & 0.25 \\
\hline SEM & 20.04 & 10.48 & 1.59 & 0.11 & 0.08 & 0.08 \\
\hline
\end{tabular}



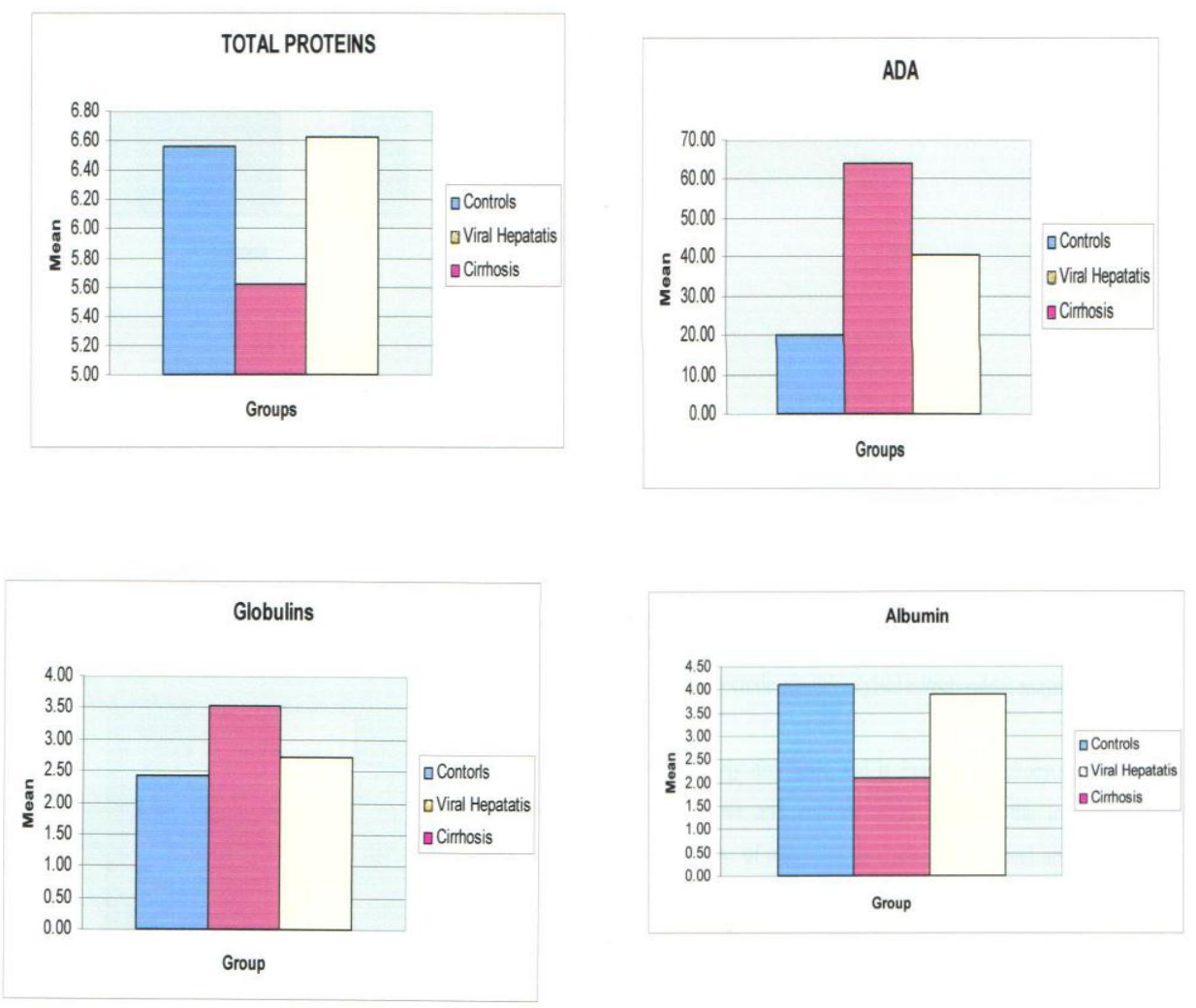

\section{Discussion}

In the present study various liver function parameters are compared between alcoholic cirrohsis, viral hepatitis, and normal individual taken as controls. The main aim of study is to evaluate the signicficance of ADA levels along with other parameters that is ALT ,AST Total proteins and A/G ratio

Mild inflamatary conditions are likely to release cytoplasmic enzymes where as necrotic conditions yield mitochondrial enzymes as well

ADA wildly distributed and is found in lymphocytes ,intestinal mucosa , splin , liver and erythrocyte. It catalyses the irreversible hydrolytic deamination of adenosine producing inosina and ammonia . Ammonia is detoxified either by conversion to urea or glutamine. Cirrhosis is the end stage liver dieseas characterized by diffuse septal fibrouses and necrosis .The necrotic tissue releases several enzymes into circulation and measurement of the level of these enzymes in serum refelects the severity of damage .

In the study group II cirrhosis , ADA is significantly raised( mean $64.08 \pm 5.9$ as compared to group III (Viral Hepatitis) and Group I (Controlled Group) (Mean 20.08 \pm 6.97 U/L) and present study co-relates with (Sanchez Rodriguez A) ${ }^{46}$.

Serum transaminases are moderately elevated in cirrhosis with mean of ALT $(50.92 \pm 7.1 \mathrm{U} / \mathrm{L})$, AST $(57.25 \pm 8.5 \mathrm{U} / \mathrm{L})(\mathrm{p}<0.01)$ when compared to group III (viral hepatitis ) and group I (control group) which is statistically significant. The increase in serum levels of AST is greater than that of ALT. This variation in elevation is owing to the fact of existence of two iso-forms of AST-cytosolic and mitochondrial. In severe necrosis the mitochondrial fraction is also released into the circulation along with the cytosomal fraction.The ration of AST to ALT is greater than $1 .{ }^{47}$ The ratio reflects the grade of fibrosis.

Serum proteins: When compared to group I $(6.558 \pm 0.382 \mathrm{~g} / \mathrm{dL})$ there is relative reduction in total protein values (mean $5.617 \pm 0.446 \mathrm{~g} / \mathrm{dL}$ ) in group II.Serum albumin levels were decreased to a greater extent $(2.09 \pm 0.202 \mathrm{~g} / \mathrm{dL})$ when compared to group I $(4.12 \pm 0.379 \mathrm{~g} / \mathrm{dL}),(\mathrm{p}<0.001)$. The low serum albumin indicates that the synthetic function of liver is affected in liver disease. The low serum albumin has also been suggested to indicate the severity of liver cell damage, malnutrition and end stage liver disease (Paul L Wolf, 1999).Serum globulins are increased (mean $3.52 \pm 0.322 \mathrm{~g} / \mathrm{dL}$ ) when compared to group I (mean $2.442 \pm 0.231 \mathrm{~g} / \mathrm{dL}$ ) ( $<<0.001)$. Hyperglobulinemia, owing to the increased activity of immune system, is a characteristic feature of chronic liver disease and once established it persists.

The reverse of $\mathrm{A} / \mathrm{G}$ ratio seen in cirrhosis which indicates the severity of liver disease (M.D.C Finnlaysen etal 1995, Daniel Ketal 1988). Viral hepatitis: Inflammatory process in the liver characterized by 
diffuse or patchy hepatocellular necrosis. The mechanism involved in the liver cell injury is through the immune system mediated cytotoxic T-cells directed at Hepatitis B virus antigen. Increase ADA activity is observed in group II, (Mean $40.73 \pm 5.27)(\mathrm{p}<0.01)$ statistically significant and correlates with the findings of Sanchez Rodriguez, (Ahmet Kalkan, Vasudha etal, Prathibha etal) $48,49,50$

Free radicals are released by activated leucocytes which cause peroxidation of membrane-lipids leading to rupture of lysosomal membrane and release of lysosomal enzymes resulting in cell necrosis. Lipid peroxidation disrupts the structural integrity of plasma membrane, as a result there occurs release of membraneassociated enzymes like ADA. (Ahmet Kalkan, Vedat Bulut etal). (Pratibha, Usha Anand etal) (Vasudha etal)

In viral hepatitis the serum levels of ADA are moderately elevated when compared to group I and II which is statistically significant. The serum transaminases shown significant raise when compared to two groups. The ALT levels are much greater than AST( mean of ALT and AST 183.45 $\pm 66.47,93.0 \pm 34.76$ ). This is because ALT is more specific to liver. Serum proteins showed no variation when compared to group I and II. Serum albumins and globulins levels were normal. The $\mathrm{A} / \mathrm{G}$ ratio is not altered.

\section{Conclusion}

Alcohol induced liver damage is the most common cause of liver disease. Ethanol metabolism generates free radical. The membrane lipids are more susceptible to free radical attack. They undergo peroxidation and results in release of membrane bound enzymes like ADA into the circulation. In addition acetaldehyde, metabolite of ethanol is highly reactive compound, it binds with proteins and form acetaldehyde adducts which in turn evokes immunological reaction leading to activation of macrophages or T-cells, resulting in increased levels of serum ADA. Increases ADA levels in viral hepatitis reflect an increase in phagocytic activity of macrophages.

In our study raised serum ADA levels are seen in cirrhosis patients when compared to normal individuals. Serum transaminases showed moderate raise when compared to normal individuals. Serum AST levels were greater than ALT. The serum AST: ALT ratio is $>1$. The total serum proteins showed marked reduction when compared to normal individuals. Serum albumin is reduced to greater extent. Serum globulins were increased when compared to normal individuals, resulting in reversal of normal A/G ratio. The reverse of $\mathrm{A} / \mathrm{G}$ ratio indicates the severity of disease.Viral hepatitis patients when compared to normal individual showed moderate raise in ADA levels, a significant raise in serum transaminases when compared to normal individuals. The serum ALT levels were greater than AST. Total serum proteins were within normal range. The serum albumin and globulin levels were normal.

Cirrhosis patients when compared to viral hepatitis patients showed marked elevation of serum ADA levels than viral hepatitis and serum transaminases were moderately raised in cirrohosis. Whereas, viral hepatitis patients showed a significant raise in ALT and AST, ALT levels are greater than AST. The total proteins were reduced in cirrhosis; in viral hepatitis they are normal. The serum albumin levels were reduced in cirrhosis and globulin levels were raised which resulted in reversal of $\mathrm{A} / \mathrm{G}$ ratio. No such change is seen in viral hepatitis.

Thus ADA is a non-specific marker of cell mediated immunity. It is not useful in diagnosing the cause of disease. But it may be helpful in adjunct with other markers of liver function test i.e., AST, ALT, Total Proteins and $\mathrm{A} / \mathrm{G}$ ratio in assessing the severity and prognosis of disease.

\section{References}

[1]. D.J. Weather well, J.G.G Ledingham and D.A. Warell. Oxford text book of medicine.

[2]. Davidson's Principle and practice of medicine

[3]. Pathogenesis, Diagnosis \& treatment of alcoholic liver diseaseMayo clinic proc 20001; 76; $1021-1029$.

[4]. Pares-A Barrerajm, cabellaria J.efal Hepatitis C virus antibodies in chronic alcoholic patients association with Severity of liver disease. Hepatology 12:1295-9; 1990 Dec.

[5]. Devlin - textbook of Biochemistry.

[6]. Niemelao-Juvenen T, Parkkila S; immunohisto chemical demonstration of acetaldehyde - modified epitopes in human liver after alcohol consumption J.Clin invest 87;1367-1991.

[7]. Lieber CS: Hepatic, metabolic \& toxic effects of ethanol-1991.

[8]. Robbins Pathology $-4^{\text {th }}$ edition

[9]. Luo j, Hwang S,Chang F, Chu C, Lai C, Wang Y, et al. simple blood tests can predict compensated liver cirrhosis in patients with chronic hepatitis C.Hepatogasroenterology 2002;49;478;-81

[10]. Hamson's Principle's \& practice of medicine $16^{\text {th }}$ edition.

[11]. Desmet, V.J; liver lesions in hepatitis B viral infection. Yale J. Biol Med 61:61 1988.

[12]. R.Franko, V.Casado, F.CIruela, C.Saura, J.Mallal-progress in neurobiology 1997.

[13]. Trotta P.P, and Ballis, M.E- structural and kinetic alterations in adenosine deaminase associated with differentiation of rat intestinal cells. 1997 Cancer Res. 37, 2297-2305

[14]. Dadonna, P.E, Orkin, Kelley-cDNA and amino acid sequences of human ADA 1985

[15]. Aronow B.J, Witte, D.P, Winginton D.A, Hutton J.J, -co-ordinate development regulation of purine catabolic expression in gastrointestinal and post implantation reproductive tracts. Jcell boil 115:179, 1991

[16]. Chang. Z.Y, Nygaard.P, Chinault A.C, and Kellems, R.E 1991.

[17]. Nyce, J.W. 1999. Insight into adenosine receptor function using antisense and gene knockout approaches. Trends pharmocol. Sci. $20,79-83$. 
[18]. Munshi, R,Pang, I.H sternweis, P.C and Linden, J. 1991. A1 adenosine receptors of bovine brain couple to tuanine nucleotidebinding proteins Gi1, Gi2, and Go. J. Biol Chem. 266, 22285-22289.

[19]. Iredale, P.A, Alexander, S.P and Hills, S.J. 1994. Coupling of a transfected human brain A1 adenosinereceptor mediated signaling in adenosine mediated inhinition of T-cell activation and expansion.

[20]. Thorn, J.A and Jarvis, S.M, 1996 . Adenosine transportes. Gen. Pharmacol. 27, 613-620.

[21]. Lelievre, V., Muller, J.M. and Falcon J.1998. Adenosine modulates cell proliferation in human colonic carcinoma. Differential behavior of HT29, DLD-1, CACO-2 and SW403 cell lines. Eur. J. Pharmacol. 341,299,308.

[22]. Green, A. 1987. Adenosine receptor down-regulation and insulin resistance following prolonged incubation of adipocytes with an A1 aadenosine receptor agonist. J.Biol chem. 262, 15702-15707.

[23]. Takasunga, S., Katada, T., Ui, M., and Hazeki, O., 1999. Enhancement by adenosine of insulin induced activation of phosphoinositide3-kinase and protein kinase B in rat adipocytes. J.Biol Chem. 274, 19545-19550.

[24]. WigintonD,A., Coleman. M.S, Hutton J.J-Purification , characterization and radioimmuno assay of ADA from human leukemic granulocytes. Biochem J-195:389 (1981).

[25]. Scrader W.P, Bryer P.J, Characterization of insoluble ADA complexing protein fromhuman kidney. Biochem, Biophysics 215107(1982).

[26]. Morrimoto C, Schlossman S.F, Structure and function of CD26 in T-Cell immune response. Dept- Immunology- 161:55(1998).

[27]. Wiginton, Kaplan D.j, States J.C, etal-complex sequence and structure of gene for human ADA.

[28]. Cederbaum S.D, Kaiatila. I, Rimoin D.L, and Stiehm E.R (1976). The chondro osseous dysplasia of ADA deficiency with severe combined immune deficiency. J-Pediator-89,737-742.

[29]. B.R. Maldhure ${ }^{1}$, S.P Bedarkar ${ }^{1}$, H.R. kulkarnal ${ }^{3}$ and S.P. paplnwar, Indian Journal of T.B, 1994, 41-161.

[30]. M.A. Piras and C. Gakis: Cerebrospinal fluid ADA activity in tuberculous meningitis: enzyme 14:311:317(1972/73)

[31]. T.Pettersson; M.Klockars; T.H. Weber; R.Von Essen schandinavian journal of rheumatology.

[32]. Carl A. Brutis, Edward R.Ashwood, David E, Bruns, Teitz text book of clinical chemistry and molecular diagnostics.

[33]. Panteghini M, Aspartate amini transferase iso-enzyme Clin-Biochem -1990:23:311:29

[34]. Dufour D.R. Lott JA,etal, Diagnosis and monitoring of hepatic injury. Clin Chem2000;46;2050-68.

[35]. Peter T Jr. All about albumin, serum albumin, biochemistry, genetics and medical applications Washington DC:AACC press 1996.

[36]. Ha J.S. Ha C.E. Chao, Peterson C.E, etal - human serum albumin and its structural variance mediate cholesterol effux from cultured endothelial cells. Biochem, Biophysics act-2003:1640 (2-3) 119-28

[37]. Kelle E, Bennholds, Analbuminemia: A follow u of the first tow cases J.J. Clin Med 1996; 127;470-80.

[38]. Hedlund J.U. Hanson L.O. Ortquist AB, Hypoalbuminemia in hospitalized patients with community acquired pneumonia 1995 ; $155: 1438-42$.

[39]. Jose L, Banales M.D, etal (1991) Chest 99/2:355

[40]. Jose M. Martinez - Vaquez, etal (1986) Gut 27:1049-1053.

[41]. Shumann G. Bonora R. Ceriotti F. etal, IFCC primary reference procedures for the measurement of catalytic activity ocnc of enzymes at $37^{0}$ Part-4, Ref Procedure-measurement of Alanine aminotransferase. Clin, chem..Lab, Med 2002:40:718-24.

[42]. Shumann G, Bonora R, ceriotti F, etal, IFCC primary reference procedure for the measurement of catalytic activity conc of enzymes at $37^{\circ}$ Part -5, Ref Procedure- measurement of Alanine aminotransferase. Clin,Chem. Lab, Med 2002:40: 725-33.

[43]. Weicheselmannbaum. Amer J, Cl;inc pathology 16:40. 